\title{
PERTUMBUHAN TIGA KELAS MUTU BIBIT MERANTI MERAH PADA TIGA IUPHHK DI KALIMANTAN
}

(Growth of three seedling quality classes of red meranti at three IUPHHK in

Kalimantan)

Oleh/By:

\section{Burhanuddin Adman}

Balai Penelitian Teknologi Perbenihan Samboja

\begin{abstract}
Study on effects of seedling quality to survival rate and growth of three species red meranti was conducted at IUPHHK PT. Sari Bumi Kusuma (PT. SBK), PT. Erna Djuliawati, Central Kalimantan and PT IKANI, East Kalimantan. The aim of this study is to give information about effects of seedling quality on survival rate and growth of three species red meranti based to Indonesian National Standart (SNI 01-5005.1-1999) after a year planted. Treatments consisted of three species red meranti and three seedling quality from wildlings at PT. SBK and two species of red meranti and three seedling quality from wildlings at PT. IKANI and PT. Erna Djuliawati. Research design was factorial completely randomized block design with 4 replications. Results shows that species, seedling quality, interactions between species and seedling quality and blocks are not significantly different on survival rate at PT SBK and PT. IKANI. At both IUPHHK, species and seedling quality gave significant effect on height and diameter growth. In common height and diameter growth of $\mathrm{S}$. leprosula is higher than other species of Shorea, where each of $146.6 \mathrm{~cm}$ and $1.6 \mathrm{~cm}$ at PT. SBK and $87.48 \mathrm{~cm}$ and $1.56 \mathrm{~cm}$ at PT. IKANI. For seedling quality in common height and diameter growth of seedling quality 1 is higher than others, where each of $142.6 \mathrm{~cm}$ and $1.6 \mathrm{~cm}$ at PT. SBK, $86.5 \mathrm{~cm}$ and $0.8 \mathrm{~cm}$ at PT. IKANI and $164.2 \mathrm{~cm}$ and $1.6 \mathrm{~cm}$ at PT. Erna Djuliawati.
\end{abstract}

Keyword: red meranti, seedling quality, wildling

\begin{abstract}
ABSTRAK
Penelitian pengaruh mutu bibit terhadap persentase hidup dan pertumbuhan tiga jenis meranti merah telah dilakukan di areal IUPHHK PT Sari Bumi Kusuma (PT. SBK), PT. Erna Djuliawati Kalimantan Tengah dan PT. IKANI di Kalimantan Timur. Tujuan penelitian ini adalah untuk memberikan informasi tentang pengaruh mutu bibit terhadap persen hidup dan pertumbuhan tiga jenis meranti merah berdasarkan Standardisasi Nasional Indonesia (SNI 01-5005.1-1999) setelah satu tahun ditanam di lapangan. Perlakuan terdiri dari tiga jenis meranti merah dan tiga kelas mutu bibit asal cabutan di PT. SBK dan dua jenis meranti merah dan tiga mutu bibit asal cabutan di PT. IKANI dan PT. Erna Djuliawati. Rancangan percobaan yang digunakan adalah faktorial dalam pola acak lengkap berblok yang diulang sebanyak 4 kali. Hasil penelitian menunjukkan bahwa
\end{abstract}


perlakuan jenis, mutu bibit, interaksi antara jenis dan mutu bibit dan blok tidak berpengaruh nyata terhadap persentase hidup di PT. SBK dan PT. IKANI. Di kedua IUPHHK jenis dan mutu bibit memberikan pengaruh yang nyata terhadap pertumbuhan tinggi dan diameter. Secara umum riap tinggi dan diameter jenis S. leprosula lebih tinggi dibandingkan dengan jenis Shorea lainnya, dimana masing-masing sebesar 146,6 $\mathrm{cm}$ dan $1,6 \mathrm{~cm}$ di PT. SBK dan sebesar $88,2 \mathrm{~cm}$ dan $0,8 \mathrm{~cm}$ di PT. IKANI. Untuk mutu bibit secara umum pertumbuhan tinggi dan diameter mutu bibit satu lebih tinggi dibandingkan mutu bibit lainnya, dimana masing-masing sebesar 142,6 cm dan 1,6 cm di PT. SBK, sebesar $87,5 \mathrm{~cm}$ dan $0,8 \mathrm{~cm}$ di PT. IKANI dan masing-masing sebesar $164,2 \mathrm{~cm}$ dan $1,6 \mathrm{~cm}$ di PT. Erna Djuliawati.

\section{Kata kunci : meranti merah, kelas mutu bibit, cabutan}

\section{PENDAHULUAN}

Salah satu usaha untuk meningkatkan produktivitas hutan alam khususnya di Kalimantan pada saat ini telah dilakukan penanaman pada areal bekas penebangan (log get over areas) dengan program Silvikultur Intensif (SILIN) atau sistem Tebang Pilih Tanam Indonesia Intensif (TPTII). Sejak tahun 2005, pemerintah cq. Departemen Kehutanan berdasarkan SK Dirjen Bina Produksi Kehutanan Nomor: SK.221-BPH/VI-BPHA/2005 telah menetapkan enam IUPHHK model untuk melaksanakan berbagai kegiatan terkait dengan program SILIN. Pada tahun 2008 telah bertambah menjadi 25 IUPHHK dan tahun 2009 direncanakan akan bertambah menjadi 35 IUPHHK untuk mengikuti program tersebut.

Dalam program Silin terdapat beberapa jenis Dipterocarpaceae yang diprioritaskan untuk ditanam. Dipterocarpaceae merupakan salah satu famili yang mempunyai banyak jenis dan kayunya bernilai ekonomi tinggi, dengan pertumbuhan beberapa jenis Shorea yang cukup cepat seperti Shorea leprosula, S. parvifolia, S. johorensis, S. smithiana dan S. platyclados. Suparna dan Purnomo (2004) melaporkan bahwa pertumbuhan jenis tersebut pada umur 4,5 tahun rata-rata riap diameter dapat mencapai 1,8 - 1,9 cm/tahun di kawasan IUPHHK PT. Sari Bumi Kusuma, Kalimantan Tengah. Jenis-jenis tersebut diprioritaskan untuk ditanam dalam program SILIN. Soekotjo (2007) melaporkan pada uji jenis di PT Sari Bumi Kusuma berumur 4,5 tahun rata-rata riap diameter S. leprosula mencapai $18,1 \mathrm{~mm} / \mathrm{tahun}, S$. parvifolia mencapai $20,6 \mathrm{~mm} / \mathrm{tahun}, S$. platyclados mencapai 24,6 mm/tahun dan $S$. johorensis mencapai 22,4 mm/tahun.

Pertumbuhan tanaman yang baik di lapangan tentunya didukung oleh pemilihan bibit dengan kualitas baik pula. Bibit yang bermutu ditentukan oleh dua faktor, yaitu dalam dan luar. Faktor dalam diantaranya asal benih, kondisi fisik dan fisiologis benih atau bibit itu sendiri. Faktor luar yang penting antara lain air, cahaya, suhu, kelembaban udara, konsentrasi karbon dioksida, oksigen, pupuk, medium bibit, mikoriza, hama, penyakit dan gulma di persemaian (Hendromono, 
2007). Untuk mendapatkan bibit yang bermutu diperlukan penilaian mutu bibit dalam rangka upaya standardisasi. Penilaian dapat didasarkan pada fenotipe bibit karena mudah diukur dan dapat dianggap sebagai gambaran genetik. Zobel dan Talbert (1984) menjelaskan bahwa ciri atau sifat yang sering ditampilkan setiap individu tidak lepas dari pengaruh lingkungan dan genetik. Apabila fenotipenya baik maka individu tersebut memiliki potensi genetik untuk tumbuh yang baik (Schmidt, 2000).

Untuk memperoleh tegakan yang berkualitas maka telah dilakukan uji coba penanaman bibit jenis meranti di tiga IUPHHK di Kalimantan, yaitu PT. Sari Bumi Kusuma, PT. IKANI dan PT. Erna Djuliawati.

Tujuan dari penelitian ini adalah untuk memberikan informasi hasil uji coba penanaman jenis meranti berdasarkan kriteria dan indikator mutu bibit yang sesuai dengan SNI 01-5005.1-1999 di tiga IUPHHK. Hasil dari penelitian ini diharapkan dapat menjadi bahan untuk melengkapi penyusunan SNI khususnya jenis meranti.

\section{METODOLOGI PENELITIAN}

\section{A. Lokasi Penelitian dan Waktu Penelitian}

Lokasi uji coba mutu bibit telah dilakukan di tiga IUPHHK yaitu PT. Sari Bumi Kusuma (SBK), Kalimantan Tengah, PT. ITCI Kayan Inhutani (PT. IKANI) Kaltim dan PT. Erna Djuliawati, Kalteng. Ketiga IUPHHK tersebut termasuk ke dalam IUPHHK model untuk menerapkan program SILIN. Secara administrasi pemerintahan lokasi PT. SBK termasuk Kecamatan Katingan Hulu, Kabupaten Katingan, Propinsi Kalimantan Tengah, PT. IKANI termasuk kecamatan Tanjung Palas Barat, Kabupaten Bulungan, Propinsi Kalimantan Timur dan PT. Erna Djuliawati termasuk Kecamatan Seruyan Hulu Kabupaten Seruyan Propinsi Kalimantan Tengah. Penanaman dilakukan pada bulan September 2007 di PT. SBK, bulan Desember 2007 di PT. IKANI dan bulan Juni 2008 di PT. Erna Djuliawati. Pengamatan dilakukan satu tahun setelah penanaman pada masing-masing IUPHHK.

\section{B. Tanah dan Iklim}

Jenis tanah di PT. SBK dan PT. IKANI termasuk jenis Podsolik Merah Kuning dengan $\mathrm{pH}$ antara 4-5, sedangkan PT. Erna Djuliawati termasuk 44\% jenis latosol dan sebesar 56\% termasuk jenis podsolik merah kuning. Menurut klasifikasi iklim Schmidt dan Fergusson (1951) ketiga lokasi termasuk tipe iklim A dengan rata-rata curah hujan $3.388 \mathrm{~mm} /$ tahun dan hari hujan 145 hari/tahun di PT. SBK, dengan curah hujan $4.587 \mathrm{~mm} /$ tahun dan hari hujan 161 hari/tahun di PT. IKANI dan di PT. Erna Djuliawati dengan rata-rata curah hujan $3.599 \mathrm{~mm} / \mathrm{tahun}$ dan rataan hari hujan 238 hari/tahun.

Jenis tanah di PT. SBK dan PT. IKANI termasuk jenis Podsolik Merah Kuning dengan pH 
4-5, sedangkan PT. Erna Djuliawati meliputi 44\% jenis latosol dan 56\% jenis podsolik merah kuning. Menurut klasifikasi iklim Schmidt dan Fergusson (1951) ketiga lokasi termasuk tipe iklim A dengan rata-rata curah hujan $3.388 \mathrm{~mm} / \operatorname{tahun}$ dan hari hujan 145 hari/tahun di PT. SBK, dengan curah hujan $4.587 \mathrm{~mm} /$ tahun dan hari hujan 161 hari/tahun di PT. IKANI dan di PT. Erna Djuliawati dengan rata-rata curah hujan $3.599 \mathrm{~mm} /$ tahun dan rataan hari hujan 238 hari/tahun.

\section{Bahan dan Alat}

Bahan yang digunakan tiga jenis bibit meranti merah ( $S$. leprosula, S. parvifolia dan S. johorensis) di PT. SBK, sedangkan di PT. IKANI dan PT. Erna Djuliawati terdiri dari dua jenis, yaitu $S$. leprosula dan S. parvifolia. Seluruh bibit yang digunakan berasal dari cabutan dan telah dipelihara selama tujuh bulan di persemaian. Bibit yang diuji coba diklasifikasikan ke dalam dua kelas mutu bibit meranti yang telah tersedia (SNI 01-5005.1-1999) ditambah dengan satu kelas mutu bibit di bawahnya, yaitu dengan tinggi $<35 \mathrm{~cm}$ dan diameter $<4,0 \mathrm{~mm}$, seperti disajikan pada Tabel 1. Peralatan lapangan yang digunakan dalam penelitian antara lain meteran, kaliper, mistar dan kamera.

Tabel(Table)1. Kriteria mutu bibit Dipterocarpaceae (Criteria of seeding quality of Dipterocarpaceae).

\begin{tabular}{|c|l|c|c|c|}
\hline \multirow{2}{*}{$\begin{array}{c}\text { Noum } \\
\text { (Ner) }\end{array}$} & \multicolumn{1}{|c|}{$\begin{array}{c}\text { Kriteria penilaian } \\
\text { (Assessment criteria) }\end{array}$} & \multicolumn{3}{|c|}{ Mutu bibit (Seedling quality) } \\
\cline { 3 - 5 } & \multicolumn{1}{|c|}{1} & 2 & 3 \\
\hline 1. & Kekompakan media (Compactness media) & - & - & - \\
\hline 2. & Tinggi (Height) & $50-65 \mathrm{~cm}$ & $35-49 \mathrm{~cm}$ & $<35 \mathrm{~cm}$ \\
\hline 3. & Diameter (Diameter) & $5,0-8,0 \mathrm{~mm}$ & $4,0-4,9 \mathrm{~mm}$ & $<4,0 \mathrm{~cm}$ \\
\hline 4. & Nilai kekokohan bibit (Seedling mbustness) & $6,3-10,8$ & $8,8-12,0$ & - \\
\hline 5. & Pucuk / akar (Bud / root) & - & - & - \\
\hline 6. & $\begin{array}{l}\text { Persentase kolonisasi mikoriza } \\
\text { (Mycorrhiza colonization persentage) }\end{array}$ & - & - & - \\
\hline
\end{tabular}

\section{Rancangan Percobaan}

Penelitian ini menggunakan Rancangan Acak Kelompok Faktorial 3 x 3 di IUPHHK PT. SBK dan 2 x 3 di PT. IKANI dan PT Erna Djuliawati. Faktor A adalah jenis, dimana untuk PT. SBK terdiri dari A1 $=$ S. leprosula, A2 $=$ S. parvifolia dan A3 $=$ S. johorensis, sedangkan untuk PT. IKANI dan PT. Erna Djuliawati terdiri dari A1 $=S$. leprosula dan A2 =S. parvifolia. Faktor B adalah kelas mutu bibit, terdiri dari B1 = Mutu bibit 1, B2 = Mutu bibit 2 dan B3 = Mutu bibit 3 .

Masing-masing perlakukan terdiri dari 4 ulangan dan masing-masing ulangan bibit ditanam sebanyak 100 bibit. Jumlah bibit yang ditanam adalah 100 x 4 × 3 × $3=3.600$ bibit di PT. SBK, serta di PT. IKANI dan PT. Erna Djuliawati masing-masing sebanyak 100 × 4 × 2 × $3=2.400$ bibit. 
Dengan jarak tanam 2,5 m dan jarak antar jalur $20 \mathrm{~m}$, maka luas areal penanaman di PT. SBK seluas 18 ha, dan masing-masing 12 ha di PT. IKANI dan PT. Erna Djuliawati.

\section{E. Penanaman di Lapangan}

Sebelum penanaman dilakukan terlebih dahulu dilakukan penyiapan lahan sesuai dengan pedoman teknis sistem Tebang Pilih Tanam Indonesia Intensif(TPTII), bibit ditanam menggunakan sistem jalur dengan jarak antar bibit di dalam jalur 2,5 $\mathrm{m}$ dan jarak antar jalur $20 \mathrm{~m}$ serta lebar jalur 3 $\mathrm{m}$ vertikal. Semua tumbuhan yang ada di dalam jalur penanaman dibersihkan sepanjang $250 \mathrm{~m}$.

Kegiatan penyiapan lahan meliputi pembersihan jalur, pemasangan ajir, pembuatan lubang tanam dan penanaman. Pembersihan jalur dilakukan dengan membersihkan jalur penanaman dari tumbuhan dengan lebar $3 \mathrm{~m}$ vertikal, baik secara manual maupun mekanis. Lubang tanam dibuat di tengah jalur dengan ukuran lubang $40 \mathrm{~cm}$ x $40 \mathrm{~cm}$ dengan kedalaman $30 \mathrm{~cm}$. Sebelum dilakukan penanaman, lubang tanam diisi dengan tanah bagian atas (top-soil) yang diambil di sekitar jalur antara.

Setelah satu tahun ditanam, pengukuran tinggi dilakukan menggunakan alat ukur meteran yang dibuat dari galah yang telah diberi tanda meteran. Pengukuran tinggi dilakukan mulai dari pangkal pohon sampai ujung pohon (pucuk) dan diameter diukur $10 \mathrm{~cm}$ dari permukaan tanah dengan alat ukur kaliper. Untuk pemeliharaan disesuaikan dengan petunjuk teknis TPTII, tetapi tidak dilakukan penyulaman.

\section{F. Analisis Data}

Data yang dianalisis adalah persen hidup bibit, pertambahan (riap) tinggi dan diameter setelah satu tahun ditanam di lapangan. Sebelum data dianalisis, terlebih dahulu dilakukan uji kenormalan untuk data persen hidup. Apabila penyebaran data tidak normal maka dilakukan transformasi data berdasarkan Tabel Transformasi Arcsin $\sqrt{ }$ persentase (Steel dan Torrie, 1995). Apabila hasil Uji F hitung menunjukkan adanya pengaruh perlakuan maka dilakukan uji lanjutan dengan uji beda nyata Tukey (Steel dan Torrie, 1995; Haeruman, 1975). Untuk data penunjang kualitas mutu bibit dilakukan penilaian terhadap nilai kekokohan, nisbah tinggi dan akar (top root ratio), kekompakan media dan kolonisasi mikoriza.

Untuk penilaian kekokohan bibit dan top root ratio pada setiap kelas mutu bibit diambil masing-masing 10 bibit sebagai contoh untuk masing-masing jenis. Kekokohan bibit dihitung sebagai nisbah antara tinggi bibit $(\mathrm{cm})$ dengan diameter $(\mathrm{mm})$ (Jayusman, 2005) dan nilai nisbah tinggi dan akar (top root ratio) ditentukan berdasarkan pengukuran yang dihitung sebagai nisbah antara tinggi bibit $(\mathrm{cm})$ dengan panjang akar $(\mathrm{cm})$. Penilaian ini dilakukan di persemaian setelah bibit diseleksi baru ditanam di lapangan. Untuk kolonisasi mikoriza dihitung jumlah akar yang terinfeksi mikoriza dan tidak terinfeksi mikoriza dengan alat mikroskop di laboratorium Balai 
Penelitian Teknologi Perbenihan Samboja. Untuk kekompakan media dilakukan pada saat penanaman.

\section{HASIL DAN PEMBAHASAN}

\section{A. Persentase Hidup Tanaman di Tiga IUPHHK}

Dari hasil analisis keragaman bahwa perlakuan jenis, mutu bibit, interaksi antara jenis dan mutu bibit dan blok tidak menunjukkan perbedaan yang nyata terhadap persen hidup dari jenis meranti merah di dua IUPHHK, yaitu PT. SBK dan PT. IKANI seperti disajikan pada Tabel 2.

Tabel 2 memperlihatkan bahwa persen hidup untuk ketiga kelas mutu bibit dan jenis meranti merah cukup bervariasi di dua lokasi IUPHHK PT. SBK dan PT. IKANI, akan tetapi hasil analisis ragam tidak menunjukkan perbedaan yang nyata di setiap lokasi. Sedangkan di PT. Erna Djuliawati blok dan mutu bibit berbeda nyata terhadap persen hidup, seperti di sajikan pada :

Tabel(Table) 2. Rata-rata persen hidup setelah ditransformasi berdasarkan jenis dan mutu bibit di PT. SBK dan PT. IKANI setelah satu tahun ditanam di lapangan (Average of survival rate after transformed based on species and seedling quality at PT. SBK and PT. IKANI after a year planted).

\begin{tabular}{|c|c|c|c|c|c|c|}
\hline \multirow{2}{*}{$\begin{array}{c}\text { No } \\
\text { (Number) }\end{array}$} & \multirow{2}{*}{ IUPHHK } & \multirow{2}{*}{$\begin{array}{c}\text { Jenis } \\
\text { (Species) }\end{array}$} & \multicolumn{3}{|c|}{ Mutu bibit (Seedling quality) } & \multirow{2}{*}{$\begin{array}{l}\text { Rata-rata } \\
\text { (Average) }\end{array}$} \\
\hline & & & 1 & 2 & 3 & \\
\hline \multirow[t]{3}{*}{1} & \multirow{3}{*}{$\begin{array}{l}\text { PT. SBK } \\
\text { Kalteng }\end{array}$} & S. leprosula & 71,9 & 69,9 & 68,2 & 70,0 \\
\hline & & S. parvifolia & 69,7 & 69,6 & 71,9 & 70,4 \\
\hline & & S. johorensis & 67,8 & 71,5 & 61,3 & 66,9 \\
\hline \multirow[t]{2}{*}{2} & \multirow{2}{*}{$\begin{array}{l}\text { PT. IKANI } \\
\text { Kaltim }\end{array}$} & S. leprosula & 78,9 & 76,8 & 74,1 & 76,6 \\
\hline & & S. parvifolia & 74,0 & 74,6 & 72,8 & 73,8 \\
\hline
\end{tabular}

Tabel (Tabel) 3. Rata-rata hasil uji beda nyata Tukey blok dan mutu bibit terhadap persentase hidup jenis meranti setelah ditransformasi setelah satu tahun ditanam di PT. Erna Djuliawati (average results of significant different test of Tukey on survival rate of meranti after transformed after one year planted at PT.Erna Djuliawati)

\begin{tabular}{|c|c|c|c|}
\hline $\begin{array}{c}\text { Blok } \\
(\text { Block })\end{array}$ & $\begin{array}{c}\text { Persentase hidup } \\
\text { (Survival rate) } \\
(\%)\end{array}$ & $\begin{array}{c}\text { Mutu bibit (Seedling } \\
\text { quality })\end{array}$ & $\begin{array}{c}\text { Persentase hidup } \\
\text { (survival rate) } \\
(\%)\end{array}$ \\
\hline IV & $59.8 \mathrm{a}$ & 3 & $61.2 \mathrm{a}$ \\
\hline I & $63.5 \mathrm{a}$ & 2 & $65.4 \mathrm{ab}$ \\
\hline III & $64.1 \mathrm{a}$ & 1 & $66.9 \mathrm{~b}$ \\
\hline II & $70.6 \mathrm{~b}$ & \multicolumn{2}{|}{} \\
\hline
\end{tabular}




\section{Keterangan (Remark) : Nilai rata-rata yang diikuti oleh huruf berbeda menunjukkan perbedaan yang nyata pada tingkat $5 \%$ berdasarkan uji beda nyata Tukey. (Means value followed by different letters are significantly different at 5\% level based on Tukey significant different test)}

Dalam Tabel 3 diperlihatkan persen hidup paling tinggi yaitu yang ditanam di blok II dibandingkan blok lainnya. Rendahnya persen hidup di blok IV dan I, dikarenakan pada waktu penanaman kondisi di blok I dan IV terdapat beberapa jalur penanaman yang terletak di bekas jalan sarad yang sangat terbuka. Kondisi ini menyebabkan terjadinya kematian tanaman, karena $S$. leprosula dan S. parvifolia merupakan jenis yang membutuhkan setengah naungan pada waktu muda dan selanjutnya membutuhkan cahaya penuh untuk pertumbuhannya (Mok, 1993). Priadjati (2003) menyatakan bahwa $S$. leprosula merupakan jenis yang memerlukan cahaya pada tahap awal pertumbuhan $60-70 \%$ (intensitas cahaya relatif) untuk semai dan $74-100 \%$ untuk tingkat pancang.

Kelas mutu bibit tiga memperlihatkan persentase hidup yang paling rendah dan berbeda nyata dibandingkan dengan kelas mutu satu dan dua. Rendahnya persen hidup untuk kelas mutu bibit tiga dikarenakan ukuran bibit kecil, yaitu tinggi $<35 \mathrm{~cm}$ dan diameter $<4$ mm dibandingkan kelas mutu bibit satu dan dua. Hal ini ternyata bahwa bibit berukuran kecil berpengaruh terhadap daya tahan tanaman pada saat pengangkutan dan setelah penanaman di lapangan. Bibit tersebut belum siap bersaing dengan tumbuhan lain di sekitarnya dan kurang tahan terhadap proses pengangkutan, sehingga mengakibatkan kematian setelah ditanam di lapangan.

Jika dilihat persen hidup dari setiap jenis dan kelas mutu bibit cukup baik di ketiga IUPHHK, yaitu di atas 76\%. Daryadi dan Harjono (1972) melaporkan dengan besar persentase hidup tersebut selama satu tahun ditanam dikategorikan cukup baik. Ditambah lagi pada saat penanaman selama satu tahun tersebut tidak dilakukan penyulaman, tetapi hanya pemeliharaan sesuai dengan pedoman teknis TPTII. Maksud tidak dilakukan penyulaman setelah tiga bulan ditanam adalah untuk melihat kemampuan hidup dari masing-masing jenis dan kelas mutu bibit selama satu tahun ditanam di lapangan.

\section{B. Tinggi Diameter}

Hasil analisis keragaman jenis dan mutu bibit telah menunjukkan pengaruh yang nyata terhadap pertambahan tinggi (riap tinggi), sedangkan interaksi antara jenis dan mutu bibit dan blok tidak menunjukkan perbedaan yang nyata terhadap riap tinggi bibit setelah satu tahun ditanam di lapangan, baik di PT. SBK maupun di PT. IKANI. Tetapi pada PT. Erna Djuliawati jenis dan interaksi antara jenis dan mutu bibit berpengaruh nyata terhadap riap tinggi. Untuk mengetahui jenis dan mutu bibit mana yang riapnya lebih tinggi telah dilakukan uji beda nyata, seperti disajikan pada Tabel 4 dan 5 .

Dalam Tabel 4 ditunjukkan bahwa riap tinggi jenis $S$. leprosula lebih tinggi dan berbeda 
nyata dibandingkan dengan jenis lainnya, kecuali dengan jenis $S$. parvifolia tidak menunjukkan perbedaan yang nyata terhadap riap tinggi di PT. SBK. Berdasarkan hasil uji jenis yang di lakukan oleh PT. SBK pada umur satu tahun ternyata riap tinggi dan diameter pada umur satu tahun jenis S. leprosula lebih tinggi dibandingkan jenis Shorea lainnya, yaitu sebesar 160,3 cm dan 1,7 cm (PT. SBK, 2007), di PT. IKANI sebesar 68,3 cm dan 0,9 cm (PT. IKANI, 2007) dan sebesar 180,3 cm dan 176,6 cm (PT. Erna Djuliawati, 2008). Soekotjo (2007) menyatakan bahwa S. leprosula adalah salah satu jenis meranti merah yang cukup cepat pertumbuhannya dibandingkan dengan jenis meranti merah lainnya.

Tabel(Table) 4. Hasil uji beda Tukey terhadap riap tinggi berdasarkan jenis di ketiga IUPHHK setelah ditanam satu tahun di lapangan (results of Turkey significant difference test on height increment based on species at three IUPHHK after one year planted).

\begin{tabular}{|c|l|c|r|}
\hline $\begin{array}{c}\text { No } \\
\text { (Number) }\end{array}$ & \multicolumn{1}{|c|}{ IUPHHK } & Jenis ( Species $)$ & $\begin{array}{r}\text { Riap tinggi (Height } \\
\text { increment })(\mathrm{cm})\end{array}$ \\
\hline 1 & PT. SBK, Kalteng & S. johorensis & $103,0 \mathrm{a}$ \\
\cline { 3 - 4 } & & S. parvifolia & $142,6 \mathrm{~b}$ \\
\cline { 3 - 4 } & & S. leprosula & $146,6 \mathrm{~b}$ \\
\hline 2 & \multirow{2}{*}{ PT. IKANI , Kaltim } & S. parvifolia & $75,1 \mathrm{a}$ \\
\cline { 3 - 4 } & & S. leprosula & $88,2 \mathrm{~b}$ \\
\hline 3 & \multirow{2}{*}{ PT. Erna Djuliawati, Kalteng } & S. parvifolia & $159,9 \mathrm{a}$ \\
\cline { 3 - 4 } & & S. leprosula & $172,4 \mathrm{~b}$ \\
\hline
\end{tabular}

Keterangan (Remark) : Nilai rata-rata yang diikuti oleh huruf berbeda menunjukkan perbedaan yang nyata pada tingkat $5 \%$ berdasarkan uji beda nyata Tukey (Mean values followed by difference letters are significantly different at 5\% level based on Tukey significant different test)

Tabel (Table) 5. Hasil uji beda Tukey terhadap riap tinggi berdasarkan mutu bibit di PT. SBK dan PT. IKANI setelah ditanam satu tahun di lapangan (Results of Tukey significant difference test on height increment based on seedling quality at PT. SBK and PT. IKANI after one year planted).

\begin{tabular}{|c|c|c|c|}
\hline $\begin{array}{c}\text { No } \\
(\text { Number })\end{array}$ & IUPHHK & $\begin{array}{c}\text { Mutu bibit (Seedling } \\
\text { quality })\end{array}$ & $\begin{array}{c}\text { Riap tinggi (Height } \\
\text { increment })(\mathrm{cm})\end{array}$ \\
\hline \multirow{2}{*}{1} & PT. SBK, Kalteng & 3 & $116,2 \mathrm{a}$ \\
\cline { 3 - 4 } & & 2 & $133,4 \mathrm{ab}$ \\
\cline { 3 - 4 } & & 1 & $142,6 \mathrm{~b}$ \\
\hline 2 & \multirow{2}{*}{ PT. IKANI, Kaltim } & 3 & $73,7 \mathrm{a}$ \\
\cline { 3 - 4 } & & 2 & $83,8 \mathrm{~b}$ \\
\cline { 3 - 4 } & & 1 & $87,5 \mathrm{~b}$ \\
\hline
\end{tabular}


Keterangan (Remak) : Nilai rata-rata yang diikuti oleh huruf berbeda menunjukkan perbedaan yang nyata pada tingkat 5\% berdasarkan uji beda nyata Tukey (Means value followed by difference letters are significantly different at 5\% level based on Tukey significant difference test).

Tabel 5 untuk rata-rata riap tinggi kelas mutu bibit satu menunjukkan perbedaan yang nyata dibandingkan dengan rata-rata tinggi kelas mutu bibit tiga. Sedangkan rata-rata riap tinggi kelas mutu bibit dua tidak menunjukkan perbedaan yang nyata dengan kelas mutu bibit satu.

Hasil yang diperoleh PT. Erna Djuliawati, terjadi interaksi antara jenis dan mutu bibit seperti disajikan pada Tabel 6. Dalam Tabel 6 ditunjukkan bahwa jenis S. parvifolia dengan mutu bibit satu menunjukkan riap tinggi yang lebih baik dibandingkan mutu bibit lainnya, sedangkan untuk jenis $S$. leprosula riap tinggi mutu bibit satu terlihat lebih rendah dibandingkan mutu bibit lainnya.

Tabel (Table) 6. Hasil uji beda nyata Tukey terhadap pertambahan tinggi berdasarkan interaksi antara jenis dan mutu bibit setelah satu tahun ditanam di PT. Erna Djuliawati (Results of Tukey significant difference test on height increment based on interaction between species and seedling quality after one year planted at PT. Erna Djuliawati).

\begin{tabular}{|c|l|c|c|}
\hline $\begin{array}{c}\text { No } \\
\text { (Number) }\end{array}$ & Jenis (species) & $\begin{array}{c}\text { Mutu bibit (Seedling } \\
\text { quality })\end{array}$ & $\begin{array}{c}\text { Riap tinggi }(\text { Height } \\
\text { increment })(\mathrm{cm})\end{array}$ \\
\hline \multirow{2}{*}{1} & \multirow{2}{*}{ S. leprosula } & Mutu bibit 1 & $143,8 \mathrm{a}$ \\
\cline { 3 - 4 } & & Mutu bibit 2 & $162,2 \mathrm{~b}$ \\
\cline { 3 - 4 } & & Mutu bibit 3 & $173,7 \mathrm{~b}$ \\
\hline \multirow{2}{*}{2} & \multirow{2}{*}{ S. parvifolia } & Mutu bibit 2 & $163,3 \mathrm{a}$ \\
\cline { 3 - 4 } & & Mutu bibit 3 & $169,4 \mathrm{a}$ \\
\cline { 3 - 4 } & & Mutu bibit 1 & $184,6 \mathrm{~b}$ \\
\hline
\end{tabular}

Keterangan (Remark) : Nilai rata-rata yang diikuti oleh huruf berbeda menunjukkan perbedaan yang nyata pada tingkat $5 \%$ berdasarkan uji beda nyata Tukey (Means value followed by different letters are significantly different at $5 \%$ level based on Tukey significant difference test).

Untuk jenis dan mutu bibit memberikan pengaruh yang nyata terhadap riap diameter. Interaksi antara jenis dan mutu bibit dan blok tidak menunjukkan perbedaan yang nyata terhadap riap diameter setelah satu tahun ditanam baik di PT. SBK maupun di PT. IKANI. Akan tetapi di lokasi PT. Erna Djuliawati hanya blok yang berpengaruh nyata terhadap pertumbuhan diameter. Untuk mengetahui sejauh mana perbedaan antara jenis dan mutu bibit dan terhadap riap diameter telah dilakukan uji lanjutan dengan uji Tukey. Hasil uji Tukey pada disajikan pada Tabel 7.

Tabel 7 memperlihatkan bahwa riap diameter jenis $S$. leprosula lebih tinggi dan berbeda nyata dibandingkan dengan jenis lainnya di dua lokasi. Untuk rata-rata riap diameter kelas mutu 
bibit satu lebih tinggi dibandingkan dengan rata-rata riap diameter kelas mutu bibit tiga. Sedangkan dengan rata-rata riap diameter kelas mutu bibit dua di PT. SBK tidak menunjukkan perbedaan yang nyata terhadap riap diameter satu setelah satu tahun ditanam di lapangan. Untuk di PT. IKANI ratarata riap diameter kelas mutu bibit satu lebih tinggi dan berbeda nyata dengan kelas mutu bibit lainnya. Sedangkan di PT. Erna Djuliawati hasil uji beda nyata Tukey setelah satu tahun ditanam menunjukkan riap tinggi dan diameter yang di tanam di blok III lebih tinggi dibandingkan dengan yang ditanam di blok IV dan II, tetapi tidak berbeda nyata, yaitu masing-masing sebesar 179,7 cm, $177,3 \mathrm{~cm}$ dan 165,8 cm, dengan diameter masing-masing sebesar 2,6 cm di blok III dan 2,6 di blok IV. Setelah satu tahun ditanam pertumbuhan tinggi dan diameter pada blok III dan IV tidak menunjukkan perbedaan. Hal ini dikarenakan oleh tegakan tinggal antara jalur setelah satu tahun telah tertutup kembali oleh permudaan alam yang dapat mengembalikan iklim mikro di lantai hutan.

Tabel (Table) 7. Hasil uji beda Tukey terhadap riap diameter berdasarkan jenis dan mutu bibit di PT. SBK dan PT. IKANI setelah ditanam satu tahun di lapangan (Results of Tukey significant difference test on diameter increment based on species and seedling quality at PT. SBK and PT. IKANI after one year planted).

\begin{tabular}{|c|l|c|c|c|c|}
\hline \multirow{2}{*}{$\begin{array}{c}\text { No } \\
(\text { Number })\end{array}$} & IUPHHK & Jenis ( Species $)$ & $\begin{array}{c}\text { Riap diameter } \\
\text { (Diameter } \\
\text { increment) }(\mathrm{cm})\end{array}$ & $\begin{array}{c}\text { Mutu } \\
\text { bibit } \\
\text { (Seedling } \\
\text { quality) }\end{array}$ & $\begin{array}{c}\text { Riap diameter } \\
\text { (Diameter } \\
\text { increment) }(\mathrm{cm})\end{array}$ \\
\hline \multirow{2}{*}{1} & \multirow{2}{*}{$\begin{array}{l}\text { PT SBK, } \\
\text { Kalteng }\end{array}$} & S. johorensis & $1,2 \mathrm{a}$ & 3 & $1,2 \mathrm{a}$ \\
\cline { 3 - 6 } & S. parvifolia & $1,4 \mathrm{a}$ & 2 & $1,4 \mathrm{ab}$ \\
\cline { 2 - 6 } & S. leprosula & $1,6 \mathrm{~b}$ & 1 & $1,6 \mathrm{~b}$ \\
\hline 2 & PT IKANI, & S. parvifolia & $0,6 \mathrm{a}$ & 3 & $0,6 \mathrm{a}$ \\
\cline { 2 - 6 } & Kaltim & S. leprosula & $0,8 \mathrm{~b}$ & 2 & $0,7 \mathrm{~b}$ \\
\hline
\end{tabular}

Keterangan (Remark) : Nilai rata-rata yang diikuti oleh huruf berbeda menunjukkan perbedaan yang nyata pada tingkat $5 \%$ berdasarkan uji beda nyata Tukey (Means value followed by difference letters are significantly different at $5 \%$ level based on Tukey significant difference test).

Pertumbuhan diameter batang merupakan sifat yang sangat penting, karena riap diameter berpengaruh terhadap perkembangan tanaman. Oleh karena itu perlu diupayakan pemilihan jenis yang mempunyai pertumbuhan diameter batang yang cepat (fast growing). Seperti diketahui bahwa jenis-jenis yang ditanam dalam kegiatan program SILIN adalah jenis-jenis meranti yang mempunyai riap diameter cukup cepat. Jenis tersebut antara lain S. leprosula, S. parvifolia, $S$. johorensis, S. smithiana dan S. platyclados (Soekotjo, 2007).

Dari hasil uji Tukey terhadap kelas mutu bibit terhadap persentase hidup, riap tinggi dan diameter di ketiga lokasi IUPHHK model menunjukkan kualitas mutu bibit satu dan dua 
berdasarkan SNI 01-5005.1-1999 telah memberikan riap tinggi dan diameter lebih tinggi dibandingkan dengan kelas mutu tiga, yaitu di PT. SBK, sebesar 142,6 cm dan 1,6 cm, di PT. IKANI sebesar 88,2 cm dan 0,8 cm dan di PT. Erna Djuliawati sebesar 164,2 cm dan 1,6 cm. Dengan demikian kelas mutu bibit satu dan dua berdasarkan SNI 01-5005.1-1999 telah menunjukkan hasil cukup baik terhadap persentase hidup dan pertumbuhan tinggi dan diameter, sehingga SNI 015005.1-1999 untuk jenis meranti yang telah dibuat dapat digunakan sebagai standardisasi untuk penanaman jenis meranti.

\section{Kekokohan bibit, Nisbah tinggi dan akar, Kekompakan media, dan Kolonisasi mikoriza}

Dalam penentuan mutu bibit selain pertumbuhan tinggi dan diameter juga digunakan indikator lainnya, yaitu nilai kekokohan, nisbah tinggi dan akar (top root ratio), kekompakan media dan kolonisasi mikoriza pada saat sebelum ditanam. Indikator ini sangat penting untuk menunjang kualitas bibit sebelum ditanam di lapangan.

Jayusman (2006) melaporkan bahwa nisbah tinggi dan diameter (nilai kekokohan), Nisbah tinggi dan panjang akar (top root ratio) sebelum bibit ditanam adalah karakter penunjang yang sering dipakai untuk menilai sifat morfologis bibit di persemaian. Kekokohan bibit menggambarkan keseimbangan pertumbuhan antara tinggi dan diameter bibit di lapangan. Nilai kekokohan yang tinggi akan menunjukkan kemampuan hidup yang rendah karena tidak seimbang perbandingan tinggi bibit dengan diameternya. Nilai kekokohan bibit di persemaian berkisar antara 6,3-10,8 dikelompokkan baik (SNI 01-5005.1-1999).

Dari hasil perhitungan rata-rata kekokohan bibit meranti jenis $S$. leprosula dari bibit mutu satu yang berasal dari cabutan yang dipelihara selama tujuh bulan di persemaian dengan nilai kekokohan sebesar $9.4 \pm 0.28$ di PT. SBK dan $9.5 \pm 0.34$ di PT. IKANI dan $9.8 \pm 0.28$ di PT. Erna Djuliawati termasuk dalam kategori yang baik. Makin kecil nisbah tinggi dan panjang akar akan menunjukkan pertumbuhan kurang baik. Nilai nisbah tinggi dan panjang akar yang baik berkisar antar 2 - 3 termasuk dikelompokkan baik (SNI 01-5005.1-1999). Berdasarkan hasil penilaian uji coba menunjukkan rata-rata sebesar 2,2 di PT SBK dan 2,6 di PT. IKANI dan 2,6 di PT. Erna Djuliawati sehingga dikategorikan baik. Selain media yang digunakan untuk pertumbuhan bibit dari top soil pada waktu penanaman terlihat utuh atau kompak antara media dan akar tanaman dengan persentase kolonisasi akar bermikoriza rata-rata di atas $60 \%$.

\section{KESIMPULAN DAN SARAN}

\section{A. Kesimpulan}

Berdasarkan hasil uji coba SNI 01-5005.1-1999 di lapangan maka diperoleh hasil sebagai berikut :

1. Persen hidup tanaman di ketiga IUPHHK model cukup baik, yaitu rata lebih dari $74 \%$ setelah 
ditanam satu tahun di lapangan tanpa penyulaman.

2. Secara umum riap tinggi dan diameter jenis $S$. leprosula lebih tinggi dibandingkan dengan jenis Shorea lainnya, walaupun secara statistik tidak berbeda dengan S. parvifolia di PT. SBK.

3. Secara umum kelas mutu bibit satu memberikan riap tinggi dan diameter lebih tinggi dibandingkan dengan kelas mutu lainnya, walaupun secara statistik tidak berbeda nyata dengan kelas mutu bibit dua pada ketiga IUPHHK.

4. Rata-rata nilai kekokohan bibit dan nisbah batang dan akar kelas mutu bibit satu cukup baik sebagai penunjang bibit untuk ditanam di lapangan, yaitu masing-masing di atas nilai 9 dan 2 .

5. Media yang digunakan utuh atau kompak dengan persentase kolonisasi akar bermikoriza di atas $60 \%$.

6. Pengujian SNI 01-5005.1-1999 telah memberikan hasil yang cukup baik terhadap persentase hidup dan pertumbuhan tinggi dan diameter.

\section{B. Saran-Saran}

Perlu dilakukan uji coba terhadap bibit jenis dipterokarpa lainnya dengan bibit berasal dari cabutan atau benih.

\section{UCAPAN TERIMA KASIH}

Penulis mengucapkan terima kasih kepada Bapak (Alm.) Dr. Mulyana Omon selaku peneliti dalam kegiatan ini. Ucapan terima kasih juga ditujukan kepada manajer PT. Sari Bumi Kusuma, PT. IKANI dan PT. Erna Djuliawati yang memberikan ijin penelitian pada areal kerjanya, serta semua pihak yang telah membantu kelancaran pelaksanaan kegiatan penelitian ini yang tidak dapat disebutkan satu persatu. Semoga tulisan ini bermanfaat bagi yang membutuhkan.

\section{DAFTAR PUSTAKA}

Daryadi, L. dan Harjono (1972). Sendi-sendi silvikultur. Lembaga Penelitian Kehutanan, Bogor.

Haeruman, H. 1975. Prosedur analisa rancangan percobaan. bagian pertama. Bagian Perentjanaan Hutan. Departemen Mangemen Hutan, Fakultas Kehutanan, IPB, Bogor. 78 h.

Hendromono. 2007. Bibit berkualitas sebagai kunci pembuka keberhasilan hutan tanaman dan rehabilitasi hutan. Orasi Pengukuhan Profesor Riset Bidang Pengembangan Silvikultur. Badan Litbang Kehutanan, Jakarta, (Tidak dipublikasikan).

Jayusman. 2005. Evaluasi keragaman genetik bibit surian di persemaian. Wana Benih Vol. 7 No. 1. Pusat Penelitian dan Pengembangan Hutan Tanaman. Yogyakarta. 
Mok, S.T. 1993. Current research on artificial regeneration of Dipterocarps. FORSPA Publication 8. Forestry Research Support Program for Asia \& The Pacific (FORSPA). Kuala Lumpur. Malaysia.

Priadjati, A. 2003. Dipterocarpaceae : Forest fire and forest recovery. Tropenbos International. The Tropenbos Foundation. Wageningen. The Netherlands.

PT. Erna Djuliawati, 2008. Status pengelolaan silvikultur intensif IUPHHK PT Erna Djuliawati. Progress report dua tahun, Kabupaten Seruyan dan Katingan, Propinsi Kalimantan Tengah.

PT. IKANI. 2007. TPTI Intensif di PT IKANI. Prosiding Seminar Pengembangan Hutan Tanaman Dipterokarpa Dan Ekspose TPTII/Silin, Balai Besar Penelitian Dipterokarpa, Samarinda Kaltim.

PT. SBK. 2007. TPTI Intensif di PT Sari Bumi Kusuma. Prosiding Seminar Pengembangan Hutan Tanaman Dipterokarpa Dan Ekspose TPTII/Silin, Balai Besar Penelitian Dipterokarpa, Samarinda Kaltim.

Schmidt dan Fergusson, 1951. Rainfall types based on dry and wet period ratios for Indonesia with Western New Guinea. Verhandelingen No. 42. Jawatan Meteorologi dan Geofisika, Jakarta.

Schmidt, L. 2000. Pedoman penanganan benih tanaman hutan tropis dan sub tropis. Terjemahan Direktorat Jenderal Rehabilitasi Lahan dan Perhutanan Sosial.

Soekotjo. 2007. Pengalaman dari uji jenis dipterokarpa umur 4,5 Tahun Di PT SARI BUMI KUSUMA Kalteng. Prosiding Seminar Pengembangan Hutan Tanaman Dipterokarpa Dan Ekspose TPTII/Silin, Balai Besar Penelitian Dipterokarpa, Samarinda Kaltim, tanggal 4-5 September 2007 Di Samarinda

Standardisasi Nasional Indonesia (SNI) 01-5005.1-1999. Standardisasi mutu bibit jenis meranti. Badan Standardisasi National, Jakarta.

Steel, R. G. D., dan J. H. Torrie. 1995. Prinsip dan Prosedur Statistika: suatu pendekatan biometric (Terjemahan). PT. Gramedia Pustaka Utama. Jakarta.

Suparna, N. dan Purnomo., 2004. Pengalaman membangun hutan tanaman meranti di PT Sari Bumi Kusuma Kalimantan Tengah. Makalah disampaikan pada Seminar Nasional dalam rangka 70 tahun Prof. Dr. Ir. Soekotjo dengan tema Visi Silvikultur Indonesia menyongsong Kehutanan 2045 tanggal 4-5 Maret 2004, di Yogyakarta 
Zobel, B. and J. Talbert. 1984. Applied forest tree improvement. John Wiley and Sons. Inc. New York. 